\title{
High Earth-system climate sensitivity determined from Pliocene carbon dioxide concentrations
}

\author{
Mark Pagani $^{1 \star}$, Zhonghui Liu ${ }^{1,2}$, Jonathan LaRiviere ${ }^{3}$ and Ana Christina Ravelo ${ }^{3}$
}

\begin{abstract}
Climate sensitivity-the mean global temperature response to a doubling of atmospheric $\mathrm{CO}_{2}$ concentrations through radiative forcing and associated feedbacks-is estimated at 1.5-4.5 ${ }^{\circ} \mathrm{C}$ (ref. 1). However, this value incorporates only relatively rapid feedbacks such as changes in atmospheric water vapour concentrations, and the distributions of sea ice, clouds and aerosols ${ }^{2}$. Earth-system climate sensitivity, by contrast, additionally includes the effects of long-term feedbacks such as changes in continental ice-sheet extent, terrestrial ecosystems and the production of greenhouse gases other than $\mathrm{CO}_{2}$. Here we reconstruct atmospheric carbon dioxide concentrations for the early and middle Pliocene, when temperatures were about $3-4^{\circ} \mathrm{C}$ warmer than preindustrial values $^{3-5}$, to estimate Earth-system climate sensitivity from a fully equilibrated state of the planet. We demonstrate that only a relatively small rise in atmospheric $\mathrm{CO}_{2}$ levels was associated with substantial global warming about 4.5 million years ago, and that $\mathrm{CO}_{2}$ levels at peak temperatures were between about 365 and 415 ppm. We conclude that the Earth-system climate sensitivity has been significantly higher over the past five million years than estimated from fast feedbacks alone.
\end{abstract}

The magnitude of Earth-system climate sensitivity can be assessed by evaluating warm time intervals in Earth history, such as the peak warming of the early Pliocene $\sim 4-5$ million years ago (Myr). Mean annual temperatures during the middle Pliocene $(\sim 3.0-3.3 \mathrm{Myr})$ and early Pliocene $(4.0-4.2 \mathrm{Myr})$ were $\sim 2.5^{\circ} \mathrm{C}$ (refs 3,4 ), and $4^{\circ} \mathrm{C}$ (ref. 5) warmer than preindustrial conditions, respectively. During the early Pliocene, the equatorial Pacific Ocean maintained an east-west sea surface temperature (SST) gradient of only $\sim 1.5^{\circ} \mathrm{C}$, which arguably resembles permanent El Niñolike conditions ${ }^{6}$. Meridional ${ }^{5,7}$ and vertical ocean temperature gradients ${ }^{8}$ were reduced, and deep-ocean ventilation enhanced, relative to today ${ }^{9,10}$. Deterioration in Earth's climate state from 3.5 to $2.5 \mathrm{Myr}$ led to an increase in Northern Hemisphere glaciation $^{11}$. By $\sim 2 \mathrm{Myr}$, subtropical Pacific meridional SST gradients resembled modern conditions ${ }^{5}$, and the Pacific zonal SST gradient $\left(\sim 5^{\circ} \mathrm{C}\right)$ was similar to the gradient observed today, with a strong Walker circulation ${ }^{6}$.

Tectonics and changes in ocean ${ }^{12-14}$ and atmospheric circulation $^{15,16}$ were potentially important factors in climate evolution during this time. However, an assessment of the timing of oceanographic and climate changes ${ }^{17}$, and the stability of the Greenland ice sheet to a range of possible forcings ${ }^{18}$, implicate atmospheric $\mathrm{CO}_{2}$ as the primary factor driving the warmth of the early Pliocene and the onset of Northern Hemisphere glaciation.

For this study, we evaluate the magnitude of $\mathrm{CO}_{2}$ change and Earth-system climate sensitivity during the Pliocene by using the alkenone- $\mathrm{CO}_{2}$ method to reconstruct Pleistocene-Pliocene $p \mathrm{CO}_{2}$ histories from six ocean localities. Ocean sites used in this study

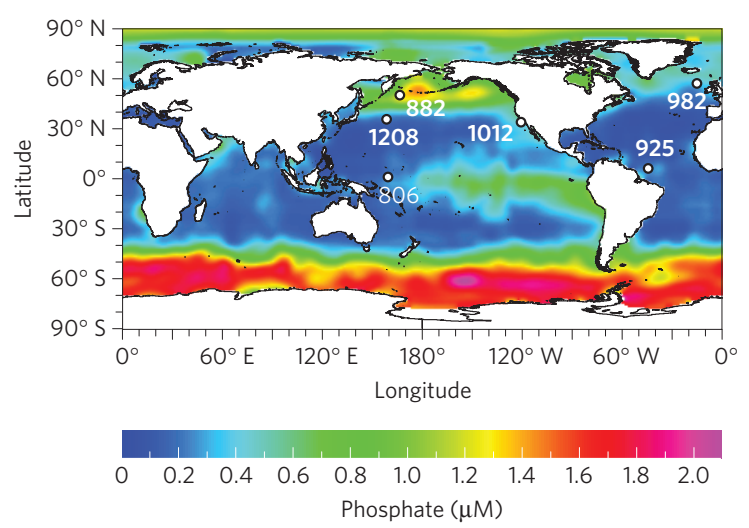

Figure 1 | Modern site locations and surface-water phosphate distributions ${ }^{30}$.

represent a range of oceanographic and algal growth environments, including Ocean Drilling Program (ODP) Sites 806, 882, 1012 and 1208 from the Pacific Ocean, and ODP Sites 925 and 982 from the Atlantic Ocean (Fig. 1) (Supplementary Information).

Alkenones are long-chained $\left(\mathrm{C}_{37}-\mathrm{C}_{39}\right)$ unsaturated ethyl and methyl ketones produced by a few species of photoautotrophic haptophyte algae in the modern ocean ${ }^{19}$. Alkenone- $\mathrm{CO}_{2}$ estimates are based on the stable carbon isotope compositions of the diunsaturated $\mathrm{C}_{37}$ methyl ketone $\left(\delta^{13} \mathrm{C}_{37: 2}\right)$ and the total carbonisotopic fractionation that occurred during algal growth $\left(\varepsilon_{\mathrm{p} 37: 2}\right)$. Chemostat incubations with nitrate-limited conditions show that $\varepsilon_{\mathrm{p} 37: 2}$ varies with the concentration of aqueous $\mathrm{CO}_{2},\left[\mathrm{CO}_{2 \mathrm{aq}}\right]$, specific growth rate, $\mu$, and cell geometry ${ }^{20}$. In contrast, dilute batch cultures with nutrient-replete conditions yield substantially lower $\varepsilon_{\mathrm{p} 37: 2}$ values, a different relationship for $\varepsilon_{\mathrm{p}}$ versus $\mu / \mathrm{CO}_{2 \mathrm{aq}}$, a minor response to $\left(\left[\mathrm{CO}_{2 \mathrm{aq}}\right]\right)$ (ref. 21), and an irradiance effect on the magnitude of $\varepsilon_{\mathrm{p} 37: 2}$ (ref. 22). Given the available experimental results, the potential exists that different growth and environmental conditions trigger different carbon isotopic responses ${ }^{23}$. However, validation of the alkenone- $\mathrm{CO}_{2}$ approach using sedimentary alkenones in the natural environment indicates that this technique can be used to resolve relatively small differences in water column $\left[\mathrm{CO}_{2 \mathrm{aq}}\right]$ when SST and phosphate concentrations $\left(\left[\mathrm{PO}_{4}{ }^{3-}\right]\right)$ and are reasonably constrained ${ }^{24}$. We use alkenone unsaturation indices $\left(U_{37}^{\mathrm{K}^{\prime}}\right)$ to determine SST and assume haptophyte production depths between 0 and $75 \mathrm{~m}$ at each site, bounding a range of $\left[\mathrm{PO}_{4}{ }^{3-}\right]$ determined from modern mean-annual-phosphate depth profiles (Supplementary Information) that is then applied to calculate a range of $p \mathrm{CO}_{2}$ estimates (Fig. 2). We assume that Pliocene $\left[\mathrm{PO}_{4}{ }^{3-}\right]$ at each site was similar to modern values or within the range of $\mathrm{PO}_{4}{ }^{3-}$ concentrations that encompass the modern photic zone.

${ }^{1}$ Department of Geology and Geophysics, Yale University, New Haven, Connecticut 06520, USA, ${ }^{2}$ Department of Earth Sciences, The University of Hong Kong, Hong Kong, China, ${ }^{3}$ Ocean Sciences Department, University of California, Santa Cruz, California 95064, USA. *e-mail: mark.pagani@yale.edu. 
a

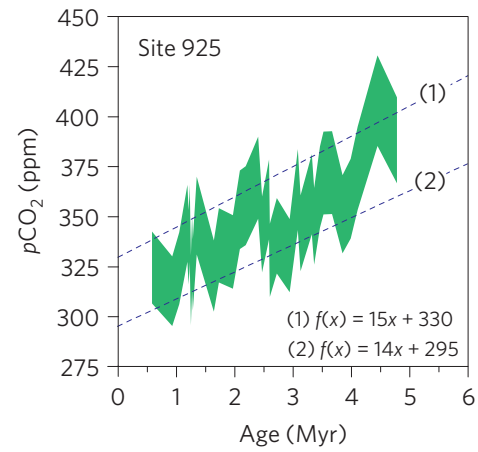

d

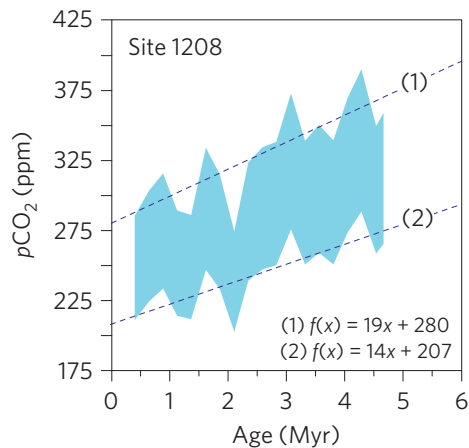

b

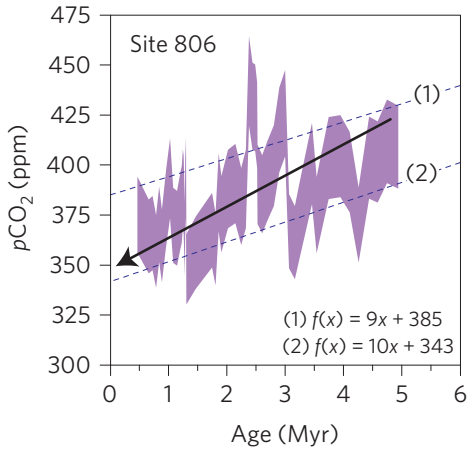

e

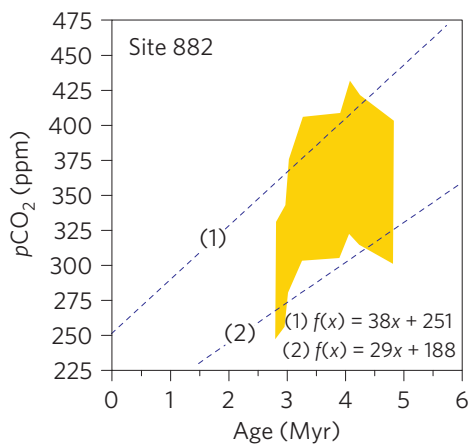

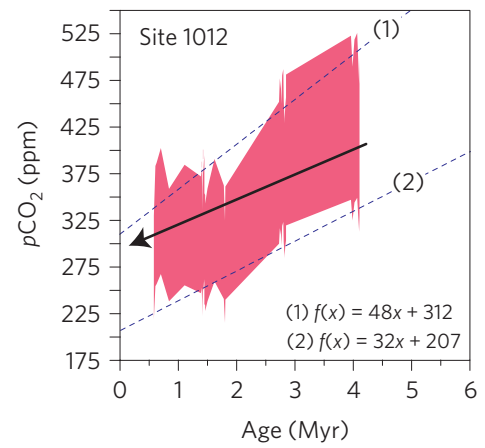

f

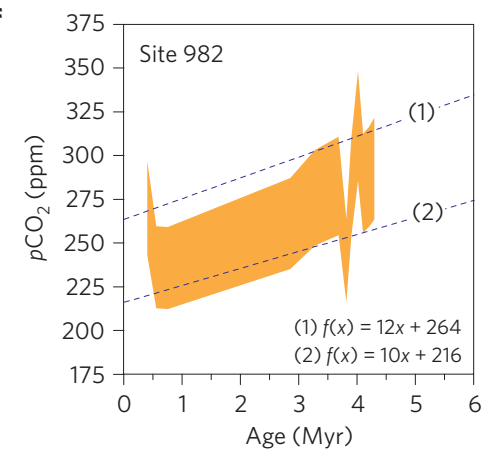

Figure 2 | Alkenone-based atmospheric $\mathbf{C O}_{\mathbf{2}}$ concentrations and $\mathbf{C O}_{\mathbf{2 s l o p e}}$. Carbon dioxide estimates are calculated from $\varepsilon_{\mathrm{p} 37: 2}$ values and $\mathrm{PO}{ }_{4}{ }^{3-}$ estimates (Supplementary Information). Upper and lower $\mathrm{CO}_{2}$ estimates represent a range calculated assuming production depths between 0 and $75 \mathrm{~m}$ depth. Dashed lines bounding $\mathrm{CO}_{2}$ estimates are linear regressions of maximum and minimum $\mathrm{CO}_{2}$ values versus time. Arrows in $\mathbf{b}$ and $\mathbf{c}$ represent $\mathrm{CO}_{2 \text { slope }}$ and early Pliocene $\mathrm{CO}_{2}$ estimates as the result of probable changes in physical oceanography and growth rates. Note the different scales for each panel.

Our $\varepsilon_{\mathrm{p} 37: 2}$ records all show a general trend of decreasing values from $\sim 5$ to $0.5 \mathrm{Myr}$, and alkenone-based temperature records (Supplementary Information) are consistent with other alkenone- and $\mathrm{Mg} / \mathrm{Ca}$-based estimates ${ }^{5}$ that support regional differences in Pliocene temperature change. Warm-pool regions in the tropical western Pacific Ocean (ODP Site 806) and western Atlantic Ocean (ODP Site 925) show no to very little warming (perhaps $\sim 0.5^{\circ} \mathrm{C}$ ) during the early Pliocene. In contrast, very large SST differences $\left(6-10^{\circ} \mathrm{C}\right)$ between the early Pliocene and preindustrial times characterize mid- and high-latitude sites $^{7}$. Large site-to-site differences in SST trends imply that some portion of observed SST change was influenced by regional changes in oceanographic conditions. For example, Site 1012 is subjected to coastal upwelling-a process that depresses mixedlayer temperatures by vertically transporting cold, nutrient-rich thermocline waters. In general, cold SSTs are notably absent from coastal upwelling regions, indicating that upwelling rates abated and/or the subsurface source of upwelling water was warmer during the early Pliocene $e^{5,25}$. In the early Pliocene, upper-ocean conditions at Site 882 (Fig. 1) in the North Pacific Ocean were less stratified, with higher opal export productivity, until $2.75 \mathrm{Myr}$, when strong water-column stratification developed ${ }^{14}$-a scenario that necessarily influenced upwelling rates and the delivery of nutrients to the mixed layer. Further, the lack of significantly warmer SSTs in the 'stable' western tropical warm pool, as recorded at Site 806, can be explained only in the context of Pliocene global warming by enhanced ocean heat transport away from the warm pool ${ }^{5}$.

Atmospheric $\mathrm{CO}_{2}$ reconstructions indicate that early Pliocene (4-5 Myr) carbon dioxide concentrations varied from site to site, with average values (that is, average of maximum and minimum estimates at each site) ranging from $\sim 390$ to $280 \mathrm{ppm}$ (Fig. 2), and a progression of decreasing atmospheric $\mathrm{CO}_{2}$ levels from
5 to $0.5 \mathrm{Myr}$. Differences in the magnitude of early Pliocene $\mathrm{CO}_{2}$ from site to site can be accounted for by differences in haptophyte growth rate, air-sea $\mathrm{CO}_{2}$ equilibrium and the level of irradiance ${ }^{22}$, as well as by differences in the regional expression of the $\left.\varepsilon_{\mathrm{p} 37: 2-}-\mathrm{PO}_{4}{ }^{3-}\right]$ calibration ${ }^{23}$ (Supplementary Information). Instead of relying on absolute $\mathrm{CO}_{2}$ values, we focus on the slope of $\mathrm{CO}_{2}$ change with time $\left(\mathrm{CO}_{2 \text { slope }}\right)$ for each site (represented by linear regressions in Fig. 2) to determine the magnitude of $\mathrm{CO}_{2}$ change before preindustrial times (Fig. 2). The $y$ intercepts of these regressions predict $\mathrm{CO}_{2}$ concentrations in the range of preindustrial to glacial $\mathrm{CO}_{2}$ levels (except for ODP Site 806, which predicts twentieth-century values) (Fig. 2), supporting the robustness of the alkenone- $\mathrm{CO}_{2}$ methodology, as well as the observation of an approximate linear decrease in $\mathrm{pCO}_{2}$ since $\sim 4.5 \mathrm{Myr}$. Changes in $\mathrm{CO}_{2}$ over the past 4.5 million years based on minimum estimates of $\left[\mathrm{PO}_{4}{ }^{3-}\right]$ (Supplementary Information) range from 45 to $144 \mathrm{ppm}$, whereas changes in $\mathrm{CO}_{2}$ based on maximum $\left[\mathrm{PO}_{4}{ }^{3-}\right.$ ] estimates range between 41 and $216 \mathrm{ppm}$. The largest change in $\mathrm{CO}_{2}$ is recorded from Pacific ODP Sites 882 and 1012, where changes in vertical water-column structure are known to have occurred ${ }^{14,17}$, and the smallest change in $\mathrm{CO}_{2}$ occurs at tropical warm-pool ODP Sites 806 and 925. Temporal resolution of the Site 882 record is poor and not used in our final $\mathrm{CO}_{2}$ evaluation.

Consideration of ocean setting and temporal changes in marine conditions, water-column structure and nutrient conditions is important in the interpretation of $\varepsilon_{\mathrm{p} 37: 2}$ trends and reconstructed $\mathrm{CO}_{2}$ records, given the dependence of $\varepsilon_{\mathrm{p} 37: 2}$ on algal growth rate and air-sea $\mathrm{CO}_{2}$ equilibrium. For example, during the earliest Pliocene, seasonal upwelling, characteristic of the modern California margin, was reduced ${ }^{17,25}$. As a consequence, mixed-layer nutrient supply and perhaps growth rates were attenuated and air-sea $\mathrm{CO}_{2}$ equilibrium enhanced at Site 1012. However, the effects of growth rate influence the value of $\varepsilon_{\mathrm{p} 37: 2}$ under low $\mathrm{CO}_{2}$ conditions ${ }^{26}$. If haptophyte growth 


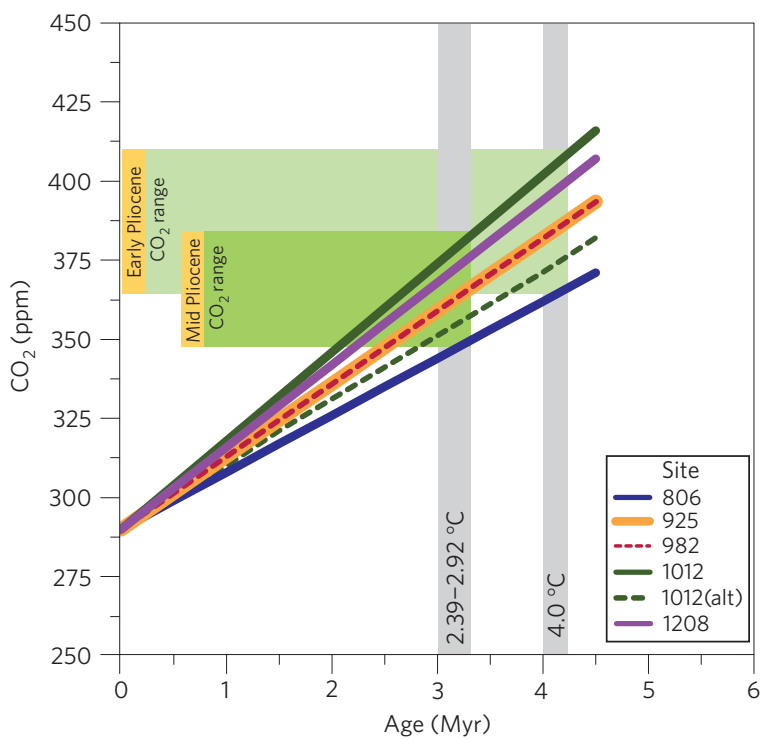

Figure 3 | Estimated $\mathrm{CO}_{2}$ trends considering probable oceanographic changes at each site. Each line represents a modified $\mathrm{CO}_{2 \text { slope }}$ for each site and the dashed green line (1012(alt)) represents an alternative nutrient scenario for Site 1012 (Supplementary Information). Vertical grey lines intersect $\mathrm{CO}_{2}$ concentrations at 3.0-3.3 and 4.0-4.2 Myr, the time intervals representing the Earth-system climate sensitivity estimates presented in the text.

rates at Site 1012 were lower in the early Pliocene and then increased as climate cooled, the $\mathrm{CO}_{2 \text { slope }}$ and the magnitude of $\mathrm{CO}_{2}$ change with time would be smaller (arrow in Fig. 2c). Alternatively, if we assume that early Pliocene surface-water nutrient concentrations at Site 1012 were lower than modern sea-surface levels, then early Pliocene calculated $\mathrm{CO}_{2}$ concentrations are lower, but the magnitude of $\mathrm{CO}_{2 \text { slope }}$ is only slightly smaller and predicts that $\mathrm{CO}_{2}$ was $\sim 90 \mathrm{ppm}$ higher in the early Pliocene relative to preindustrial concentrations (Supplementary Information). In contrast, values of $\mathrm{CO}_{2 \text { slope }}$ at Sites 925 and 806 are arguably minimum estimates. During the early Pliocene, the meridional temperature gradient was reduced, with a deeper tropical thermocline and a poleward expansion of the tropical ocean warm pool. A lower meridional SST gradient implies enhanced poleward ocean heat transport ${ }^{5}$. However, expansion of the tropical warm pool alone would act to reduce tropical ocean heat gain and meridional ocean-heat transport. This apparent contradiction is resolved if stratification in the tropics were reduced and vertical ocean-mixing rates enhanced ${ }^{5}$. If valid, tropical and extratropical sites in the early Pliocene were characterized by reduced stratification and a higher mixed-layer nutrient delivery. Higher nutrients, and associated growth rates, would bias early Pliocene reconstructed $\mathrm{CO}_{2}$ toward lower values and underestimate $\mathrm{CO}_{2 \text { slope }}$. Accordingly, the $\mathrm{CO}_{2 \text { slope }}$ would be expected to be higher at Sites 925 and 806 (arrow in Fig. 2b), resulting in a larger $\mathrm{CO}_{2}$ change since $4.5 \mathrm{Myr}$. A similar scenario would apply to subtropical Pacific Site 1208, where some enhanced vertical mixing during the early Pliocene was also likely ${ }^{5}$. These self-consistent considerations act to modulate $\mathrm{CO}_{2 \text { slope }}$ and reduce the probable range of $\mathrm{CO}_{2}$ concentrations (Supplementary Information).

In summary, $\mathrm{CO}_{2}$ estimates from a variety of oceanographic settings support a relatively minor decrease in atmospheric $\mathrm{CO}_{2}$ from the Pliocene to the Pleistocene. Potential scenarios involving uncertainties in haptophyte depth habitats, changes in oceanography, vertical mixing and nutrient distributions with time help explain site-to-site differences in the change of $\mathrm{CO}_{2}$. We estimate early Pliocene $(\sim 4.5 \mathrm{Myr})$ atmospheric $\mathrm{CO}_{2}$ at $\sim 90 \mathrm{ppm}$ to a maximum of $125 \mathrm{ppm}$ higher than preindustrial concentrations
(Fig. 3), similar to modern ( year 2009) concentrations. This result is consistent with other $\mathrm{CO}_{2}$ estimates derived from the $\delta^{13} \mathrm{C}$ of bulk organic marine carbon ${ }^{9}$, boron isotopes of marine carbonates $^{27}$ leaf-stoma densities ${ }^{28}$ and a middle to late Miocene alkenone- $\mathrm{CO}_{2}$ record that shows a persistent rise to similar $\mathrm{CO}_{2}$ levels by the latest Miocene ${ }^{29}$ (Supplementary Information). Data and modelling for the middle Pliocene $(\sim 3-3.3 \mathrm{Myr})$ indicate that the global mean temperature was $2.4-2.9^{\circ} \mathrm{C}$ warmer than preindustrial conditions $s^{3,4}$, and $\sim 4^{\circ} \mathrm{C}$ warmer during the early Pliocene ( $\sim 4-4.2 \mathrm{Myr}$; ref. 5$)$. If changes in carbon dioxide and associated feedbacks were the primary agents forcing climate over these timescales, and estimates of global temperatures are correct, then our results imply a very high Earth-system climate sensitivity for the middle $(3.3 \mathrm{Myr})$ to early $(4.2 \mathrm{Myr})$ Pliocene ranging between $7.1 \pm 1.0^{\circ} \mathrm{C}$ and $8.7 \pm 1.3{ }^{\circ} \mathrm{C}$ per $\mathrm{CO}_{2}$ doubling, and $9.6 \pm 1.4^{\circ} \mathrm{C}$ per $\mathrm{CO}_{2}$ doubling, respectively.

If only the minimum estimates are considered, Earth-system sensitivity is still substantially higher than the range of probable 'fast-feedback' climate sensitivity often discussed ${ }^{1}$, and implies that the impact of global warming acts to promote other feedbacks that substantially magnify warming over longer timescales.

\section{Methods}

Analytical methods. Sediment samples from six ODP sites (Supplementary Table S1), representing a range of oceanographic and haptophyte growth environments, were used for this investigation. We used a large amount of sediment $\left(50 \mathrm{~cm}^{3}, \sim 40-100 \mathrm{~g}\right.$ dry weight) to obtain lipids for both $U_{37}^{\mathrm{K}^{\prime}}$ and carbon isotope composition of the di-unsaturated $\mathrm{C}_{37}$ methyl ketone $\left(\delta^{13} \mathrm{C}_{37: 2}\right)$ analysis, in addition to analysing carbon isotope composition of planktonic foraminifera.

Sediments were solvent-extracted and total lipids were separated into compound classes using silica column chromatography. We carried out basic hydrolysis on the alkenone fraction and silver nitrate column chromatography before alkenone analysis. The alkenone fraction was analysed by gas chromatography to determine $U_{37}^{\mathrm{K}^{\prime}}$. External laboratory standards were repeatedly analysed to assess analytical precision. Analytical precision $(1 \sigma)$ for our laboratory standards is 0.005 unit for $U_{37}^{\mathrm{K}^{\prime}}$. The alkenone fraction was also analysed for stable carbon isotopic compositions on a Thermo Finnigan MAT 253 mass spectrometer interfaced with a Thermo Finnigan Trace GC Combustion III. We used a J\&W Scientific DB-1 capillary column $(60 \mathrm{~m} \times 0.25 \mathrm{~mm} \times 0.25 \mathrm{~mm})$. The gas chromatograph oven was programmed from $60^{\circ} \mathrm{C}$ (held for $1 \mathrm{~min}$ ) at $15^{\circ} \mathrm{C} \mathrm{min}^{-1}$ to $320^{\circ} \mathrm{C}$ and held for $35 \mathrm{~min}$ isothermally. A programmed temperature vaporizing injector was used. Helium was used as a carrier gas with a column flow rate of $2.0 \mathrm{ml} \mathrm{min}{ }^{-1}$. Carbon isotopic compositions are expressed relative to the VPDB standard, based on an in-house reference gas calibrated against the OzTech standard $\left(\delta^{13} \mathrm{C}=-40.61 \%\right)$. The analytical accuracy and precision of the MAT 253 mass spectrometer during carbon isotope measurements were $\pm 0.2 \%$ (the root-mean-square error), based on an $n-\mathrm{C}_{20}$ alkane standard injected daily. The standard error of $\delta^{13} \mathrm{C}_{37: 2}$ measurements was $\pm 0.4 \%$ or better.

Extracted sediments were washed for foraminifera selection and $\delta^{13} \mathrm{C}$ analysis ${ }^{6}$. For extratropical sites where Globogerinoides sacculifer was not available, we analysed multiple mixed-layer species. Splits of the crushed sample were separated and analysed for $\delta^{13} \mathrm{C}$ using a Fisons Prism dual-inlet gas-source ratio mass spectrometer. The precisions of NBS-19 and an in-house standard were better than $0.1 \%$ for $\delta^{13} \mathrm{C}$. Measurements of $\delta^{13} \mathrm{C}$ are reported relative to Vienna Pee Dee Belemnite.

Received 14 October 2009; accepted 18 November 2009; published online 20 December 2009

\section{References}

1. Solomon, S. et al. IPCC Climate Change 2007: The Physical Science Basis (Cambridge Univ. Press, 2007).

2. Hansen, J. et al. Target atmospheric $\mathrm{CO}_{2}$ : Where should humanity aim? Open Atmos. Sci. J. 2, 217-231 (2008).

3. Haywood, A. M. \& Valdes, P. J. Modelling Pliocene warmth: Contribution of atmosphere, oceans and cryosphere. Earth Planet. Sci. Lett. 218, 363-377 (2004).

4. Haywood, A. M. et al. Comparison of mid-Pliocene climate predictions produced by the HadAM3 and GCMAM3 general circulation models. Glob. Planet. Change 66, 208-224 (2009).

5. Brierley, C. M. et al. Greatly expanded tropical warm pool and weakened Hadley circulation in the early Pliocene. Science 323, 1714-1718 (2009).

6. Wara, M. W., Ravelo, A. C. \& Delaney, M. L. Permanent El Niño-like conditions during the Pliocene warm period. Science 309, 758-761 (2005).

7. Dowsett, H. J. in The Micropalaeontological Society (eds Williams, M., Haywood, A. M., Gregory, J. \& Schmidt, D.) 459-480 (Special Publication. Geol. Soc., 2007). 
8. Kwiek, P. \& Ravelo, A. C. Pacific Ocean intermediate and deep water circulation during the Pliocene. Palaeogeogr. Palaeoclimat. Palaeoecol. 154, 191-217 (1991).

9. Raymo, M. E., Grant, B., Horowitz, M. \& Rau, G. H. Mid-Pliocene warmth: Stronger greenhouse and stronger conveyor. Mar. Micropaleo. 27, 313-326 (1996).

10. Hodell, D. A. \& Venz-Curtis, K. A. Late Neogene history of deepwater ventilation in the Southern Ocean. Geochem. Geophys. Geosyst. 7, Q09001 (2006).

11. Mudelsee, M. \& Raymo, M. E. Slow dynamics of the Northern Hemisphere glaciation. Paleoceanography 20, PA4022 (2005).

12. Haug, G. H. \& Tiedemann, R. Effect of the formation of the Isthmus of Panama on Atlantic Ocean thermohaline circulation. Nature 393, 673-676 (1998).

13. Cane, M. A. \& Molnar, P. Closing of the Indonesian seaway as a precursor to east African aridification around 3-4 million years ago. Nature 411, 157-162 (2001).

14. Haug, G. H. et al. North Pacific seasonality and the glaciation of North America 2.7 million years ago. Nature 433, 821-825 (2005).

15. Ruddiman, W. F. \& Kutzbach, J. E. Forcing of Late Cenozoic Northern Hemisphere climate by plateau uplift in Southern Asia and the American West. J. Geophys. Res. 94, 18409-18427 (1989).

16. Harrison, T. M., Yin, A. \& Ryerson, F. J. in Tectonic Boundary Conditions for Climatic Reconstructions (eds Crowley, T. J. \& Bruke, K. C.) 39-72 (Oxford Univ. Press, 1998).

17. Ravelo, A. C., Andreasen, D. H., Lyle, M., Olivarez, A. \& Wara, M. W. Regional climate shifts caused by gradual global cooling in the Pliocene epoch. Nature 429, 263-267 (2004).

18. Lunt, D. J., Foster, G. L., Haywood, A. M. \& Stone, E. J. Late Pliocene Greenland glaciation controlled by a decline in atmospheric $\mathrm{CO}_{2}$ levels. Nature 454, 1102-1105 (2008)

19. Conte, M. H., Volkman, J. K. \& Eglinton, G. in The Haptophyte Algae (eds Green, J. C. \& Leadbeater, B. S. C.) 351-377 (Clarendon, 1994).

20. Popp, B. N. et al. Effect of phytoplankton cell geometry on carbon isotope fractionation. Geochim. Cosmochim. Acta. 62, 69-77 (1998).

21. Riebesell, U., Revill, A. T., Hodsworth, D. G. \& Volkman, J. K. The effects of varying $\mathrm{CO}_{2}$ concentration on lipid composition and carbon isotope fractionation in Emiliania huxleyi. Geochim. Cosmochim. Acta. 64, 4179-4192 (2000)
22. Rost, B., Zondervan, I. \& Riebesell, U. Light-dependent carbon isotope fractionation in the coccolithophorid Emiliania huxleyi. Limnol. Oceanogr. 47, 120-128 (2002).

23. Laws, E. A. et al. Controls on the molecular distribution and carbon isotopic composition of alkenones in certain haptophyte algae. Geochem. Geophys. Geosyst. 2, 1006 (2001).

24. Pagani, M., Freeman, K. H., Ohkouchi, K. \& Caldeira, K. Comparison of water column $\left[\mathrm{CO}_{2 \mathrm{aq}}\right]$ with sedimentary alkenone-based estimates: A test of the alkenone- $\mathrm{CO}_{2}$ proxy. Paleoceanography 17, 1009 (2002).

25. Dekens, P. S., Ravelo, A. C. \& McCarthy, M. Warm upwelling regions in the warm Pliocene, paleoceanography. Paleoceanography 22, PA3211 (2007).

26. Schulte, S., Benthien, A., Müller, P. J. \& Rühlemann, C. Carbon isotopic fractionation $\left(\varepsilon_{\mathrm{p}}\right)$ of $\mathrm{C}_{37}$ alkenones in deep-sea sediments: Its potential as a paleonutrient proxy. Paleoceanography 19, PA1011 (2004).

27. Pearson, P. N. \& Palmer, M. R. Atmospheric carbon dioxide concentrations over the past 60 million years. Nature 406, 695-699 (2000).

28. Van Der Burgh, J., Visscher, H., Dilcher, D. \& Kurschner, W. M. Paleoatmospheric signatures in Neogene fossil leaves. Science 260, 1788-1790 (1993).

29. Pagani, M., Freeman, K. H. \& Arthur, M. A. Late Miocene atmospheric $\mathrm{CO}_{2}$ concentrations and the expansion of $\mathrm{C}_{4}$ grasses. Science 285, 876-879 (1999).

30. Conkright, M. E., Levitus, S. \& Boyer, T. World Ocean Atlas 1994. Vol. 1: Nutrients NOAA Atlas NESDIS 1 (US Government Printing Office, 1994).

\section{Acknowledgements}

This work was funded by National Science Foundation grant OCE-0727306 and supported by the Yale Climate and Energy Institute. Conversations with K. Caldeira and R. DeConto were helpful and greatly appreciated.

\section{Author contributions}

All four authors were involved in drafting the paper, led by M.P. Z.L. carried out compound-specific carbon isotope analyses and alkenone temperature reconstructions, J.L. and A.C.R. analysed planktonic foraminifera $\delta^{13}$ C.

\section{Additional information}

The authors declare no competing financial interests. Supplementary information accompanies this paper on www.nature.com/naturegeoscience. Reprints and permissions information is available online at http://npg.nature.com/reprintsandpermissions. Correspondence and requests for materials should be addressed to M.P. 